Саша Д. Кнежевић*

Универзитет у Источном Сарајеву

Филозофски факултет Пале

Катедра за србистику

https://doi.org/10.18485/ai_zsjoski.2019.2.ch14

$371.3:: 811.163 .41^{\prime} 373$

\title{
НЕПОЗНАТЕ РИЈЕЧИ И ИЗРАЗИ
}

У читанкама за основну школу се уз текстове из народне књижевности по правилу као додатак појављује и одјељак Нейознат̄е ријечи и ирази или се исте непосредно појашњавају уз сам текст. Обавеза аутора читанке је да уз сваки текст ове врсте у изабраној форми понуди ову врсту помоћи ученицима. У највећој мјери овакви се појмови срећу код текстова из народне књижевности. У овом раду ћемо покушати утврдити смисао и функцију ове одреднице, тј. да ли се на овај начин богати језички фонд ученика и које се ријечи појављују у најновијим српским читанкама, као и у којој се мјери понуђена појашњења слажу са одредницама из Вуковог Срӣскої рјечника.

Кључне ријечи: читанка, непознате ријечи, рјечник, Срйски рјечник, школа, ученици

Текстови који се користе у наставном процесу у основној школи по правилу садрже ријечи које ученицима могу бити непознате или неразумљиве. Нажалост, ово се посебно односи на текстове из српске народне књижевности који су општеприсутни у основношколским читанкама. Овај феномен је посљедица чињенице да ови текстови обилују архаизмима, али и архаичним

* sasa.knezevic@ffuis.edu.ba 
облицима иначе познатих ријечи, што ученицима отежава разумијевање самог текста, а наставнику онемогућава његову квалитетну анализу.

„Несхватање речи може бити потпуно и делимично, изражено код појединаца, групе ученика, па и целог разреда. Несхваћене речи, а и несхваћен смисао познатих речи, отежавају пријем текста, па тако умањују могућности за његово доживљавање и интерпретирање. Неразумевање примењене лексике претежно се јавља у ова три вида:

a) реч је непозната и по облику и по значењу,

б) позната је реч, али је непознат појам који је њоме означен;

в) познати су облик и основно значење речи, али је непознат њен смисао у контексту (отежано је схватање због вишезначне и фигуративне употребе)" (Николић 1988: 214).

Читанке ${ }^{1}$ су уџбеници који се раде по одређеним стандардима, те се тако за непознате ријечи и изразе користе два облика појашњења уз примарни текст. Први је традиционалан и подразумијева да се ови појмови дају на крају текста експлицирани као Нейознатие ријечи и сл. и други, општеприхваћен у сав-

1 За овај рад смо користили двије старе читанке за основну школу које се више не користе у наставном плану и програму у Републици Српској и двије нове да бисмо показали како и не постоје суштинске разлике између превазиђених и актуелних уџбеника. Од стиарих смо користили Чийанку за 4. paзреg аутора Вука Милатовића, Бранка Савића и Петра Џаковића из 2011. године и Чийанку за 6. разреg из 2012. године ауторског тима који сачињавају Војислав Гаковић, Стеван Стефановић, Светозар Личина и Лука Шекара. Нову Читианку за йейи paspeg потписале су Драженка Шобот и Ирена Милошевић, а за 7. Мирјана Савић и обје су штампане 2018. године. Све читанке су објављене у издању Завода за уџбенике и наставна средства из Источног Сарајева. 
ременој пракси, да се код прозних текстова на маргини даје објашњење непознате ријечи, а што аутори приручника Boguч за gобар уибеник појашњавају у форми дефиниције: „За сваку реч за коју се претпоставља да није позната већини ученика који користе уџбеник мора се дати објашњење њеног основног значења на страници на којој се први пут појавила та реч” (Ивић, Пешикан, Антић 2008: 124). Требало би имати на уму, нарочито у нижим разредима да се и ова врста појашњења може додатно побољшати, јер „Autori čitanke mogli bi da objašnjavaju reči u margini pored teksta, a kao još jedan vid objašnjenja mogu se naći ilustracije određenih pojmova estetski prihvatljive i privlačne za učenike” (Францишковић 2011: 15). Нигдје cе, нажалост, не може наћи примјер да се од ученика тражи да илуструју неки непознати појам, онако како га они замишљају из понуђеног контекста.

Све ово се чини стога што непознате ријечи отежавају рецепцију текста и онемогућавају његово разумијевање, али се поставља и питање да ли се нейознатие ријечи могу искористити за неке друге облике интерпретације. Наиме, немогуће је тачно одредити непознате ријечи за све ученике одређеног разреда. Раније споменути Boguч, претенциозног поднаслова

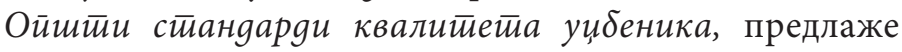
како „важи правило да је боље да се погреши у смислу да се објасни значење речи које можда ученици већ знају него да се направи грешка у обрнутом смеру" (Ивић, Пешикан, Антић 2008: 125). На примјерима из наших читанки указаћемо колико је ово бесмислен стандард који неријетко доводи чак и до комичних ситуација. С друге стране, нема примјера да се ученицима, нпр. издвоје нейознайе ријечи на маргини, а да се њима да задатак да сами покушају да дефинишу њихово значење или да се у вишим разредима од њих тражи да у 
сарадњи са наставником уз помоћ рјечника пронађу значење тих ријечи. Овакве видове проблемске наставе не предлаже ниједан од уџбеника који смо користили у овом раду. ${ }^{2}$

Вељко Брборић (2018: 477) је на трагу ове врсте рада са ученицима када каже „Ако нема објашњења у уџбенику, предметни наставник је дужан да проналази најбоље начине да их тумачи", уједно на истом мјесту упућујући како је најбоље „да приликом читања књижевног текста и сусрета са непознатом речју ученик одмах открије значење те речи". До тог открића могуће је доћи помоћу читанке, али се не смије искључити ни помоћ наставника, али ни помоћних средстава. Када су у питању српске народне пјесме и приче онда је то свакако Срйски рјечник Вука Стефановића Караџића.

Посебно је питање које рјечнике и друге приручнике су користили аутори читанки и да ли за то постоји

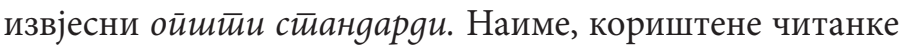
препуне су различитих грешака у тумачењу непознатих ријечи чиме се доводи у питање сам смисао ове одреднице. У Читианци за 4. разреg уз приповијетку Чарgак ни на небу ни на земљи уз појам кулаш стоји објашњењење

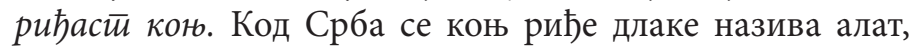
а кулаш је коњ жућкасте длаке, црне гриве и репа. У Срйском рјечнику Вук ${ }^{3}$ (1969: 313) овај појам толкује латинским појмом Equulus coloris murini, уз додатно појашњење „тако се у пјесмама зове коњ знатног четеџије

2 Аутору овог рада одбијена је читанка за девети разред основне школе у којој је поред уобичајеног начина појашњења непознатих ријечи користио и различите алтернативе којима би ангажовао ђаке и њихове наставнике као метиоgички нейрихвайльиви, без објашњења зашто би овакви облици рада на тексту то уистину и били.

3 Сви цитати из Вуковог Срӣской рјечника су преузети из фототипског издања Београд: Нолит, 1969. 
и јунака тала од Орашца". На истом мјесту налазимо на још једну врсту грешке, која је посљедица тезе да је боље објаснити јасно, него дозволити ученицима да размишљају. Појам наћерати се појашњава обликом найје-

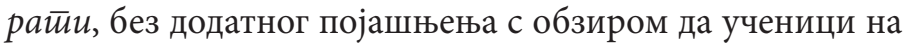
овом узрасту нису учили јотовање.

Приповијетка Во и миш у шестом разреду доноси

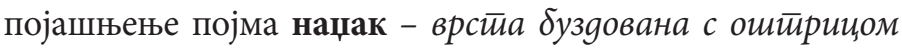
на јеgној и чекићем на gруїој сйрани. Наџак наравно није никакав буздован него старинска алатка која се користила као оруђе, али и као оружје за коју код Вука (412) налазимо појашњење „наџак је с једне стране као мала сјекирица, а с друге стране има дугачке уши”. Да се ауторима читанке понекад на само једном тексту поткраде неколико грешака најбољи примјер је уз пјесму љубавни

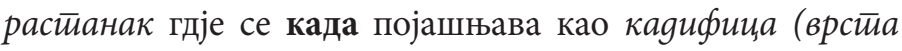
ц,вијећа). Прескочено је фундаментално појашњење да је у питању зелена каgа или зеленкаgа, које Вук (207) на латински преводи као narcissus, наводећи као примјер стихове „Два цвијета у бостану расла/плави зумбул и зелена када”. Појам мурећеп се појашњава ријечима масииило gобијено og uрвених бобиияа биљке, без обзира што је у пјесми у питању „црн мурећеп”, а код Вука (1969:375) се уз овај појам појашњава као atrementum, односно, ирно мастиило. Скоро невјероватно дјелује појашњење уз име Скендербег - син Ивана Црнојевића који се йойурчио и био санцак-бет Црне Горе, уз пјесму Паун йасе.

Као спефична врста грешке може се и посматрати неусаглашеност која узрокује различита појашњавања истог појма у различитим читанкама. Такав примјер срећемо у пјесми Марко Краљевић и беі Косйаgин у четвртом разреду гдје имамо објашњење скерлет - скуйоијена ирвена

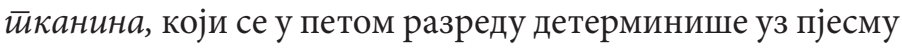
Јетирвице аяамско колено дефинише као йканина тубичасйоирвене боје. Ако у читанци за четврти разред у 
приповијеци Еро и каgија срећемо појашњење море узвик за йоgстиицаюе или ӣрекореваюе, нема разлога да се он понавља и у шестом разреду уз приповјетку Megвјеg као ӣygap, са друкчијим појашњењем, море - узречииа у іовору за изражавање различитичх расиоложења.

Да различити аутори користе различите изворе показује и примјер да се појам јасле из бајке Чарgак ни на небу ни на земљи у четвртом разреду појашњавају као йреіраgа у сйаји у коју се стиоии стиавља сијено, а у шестом уз приповијетку Во и миш као найрава у облику gуїачкоі коритиа или сандука, ӣричврћеної уза зиg, у коју се сйавља сйочна храна.

Чињеница на коју упозорава Милија Николић (1988: 215) „Много је лексичких подручја и семантичких кругова који су сасвим удаљени од искуства данашњих ученика", не може бити алиби за потребу да се појашњавају општепознати изрази неријетко помоћу потпуно непрецизних или чак мање познатих појмова. Отуда уз Вуков текст $М о \delta a$ срећемо појашњења купити сијено - сакуйљайи сијено вилама или ірабуљама, при чему није јасно како ученици који не знају значење основног појма могу знати значење објашњавајућих термина виле и ірабуль, или потпуно неразумљиво разјашњење млада - невјести $а$, гдје се опшепознат појам појашњава својим архаичним парњаком.

Овакви случајеви су неријетко и на граници комичног као у примјеру из петог разреда гдје се уз приповијетку Крейао койао сусреће појашњење каматник - човјек који йозајмљује новаи, узима камайу гдје се очигледно подразумијева да ученици разумију појам камата, али не и изведеницу каматник за коју код Вука (261) проналазимо објашњење „који узима камату на новце; каматник душу губи” које би свакако итекако припомогло адекватној рецепцији ове приповијетке. У истој читанци се у бајци Биберче среће парњак испрошена (дјевојка) - вјерена (дјевојка), који у најмању руку није 
синониман, а сам појам испрошена даје велику могућност за широка објашњења народних обичаја и разлике са савременом ситуацијом.

Понекад није лако испоштовати савремена правила прихватљивог говора па отуда уз пјесму Свейи Саво у шестом разреду срећемо чудно појашњење кљаст - кља-

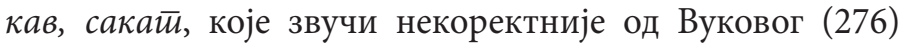
појашњења „дефектних руку, неисправан”. У истом разреду уз пјесму Цар Лазар и Царица Милица проналазимо примјер крсташ барјак - барјак са знаком крсти $а$, при чему се вјероватно подразумијева да је ђацима познат термин барјак, а да се потегло за Срйским рјечником наишли би на изванредно објашњење „vehillum cruciatum / мученичка застава”.

Занимљиво да у свом тексту Речници у чийанкама за основну школу Вељко Брборић, а позивајући се на Рајну Драгићевић, набрајајући рјечнике које треба користити у наставном процесу уопште не спомиње Срйски рјечник Вука Стефановића Караџића. У истраживачкој настави, поготово у раду на текстовима из српске народне књижевности, овај рјечник је свакако знатно изазовнији од рјечника стандардног језика или речника страних ријечи, а поготово је његова примјена природна у анализи текстова из српске народне књижевности и нейознайих ријечи који у њима препознају или не препознају аутори читанки. О неопходности употребе рјечника и обучавању ученика њиховом коришћењу Рајна Драгићевић каже: „Један од најважнијих задатака који имају наставници српског језика јесте да у ученицима пробуде потребу да се служе, да их науче где могу да их обавесте о неком питању и да их подстакну да желе да се обавесте [...] Због тога је врло важно стално упућивати ученике на језичке приручнике, пре свега на правопис и речнике”.

Коришћење Срӣскої рјечника би наравно, првенствено, требала бити обавеза аутора читанки чиме би 
се избјегле многе забуне и грешке које смо пронашли у овим читанкама, односно многе би нейознайе ријечи биле појашњене на интересантнији начин. Тако нпр. у Читиании за пети разред уз епску пјесму Јетирвице аgамско колено срећемо потпуно непрецизно објашњење ока - сииара мјера за йежину, док за исти појам у Срйском рјечнику (1969: 452) постоји поред појашњења меркантилне вриједности на њемачком језику и читава занимљива причица на српском: „У Србији се мјери на оку све, н. п. хљеб, месо, брашно, вино, ракија итд; у оци злата има четири стотине дуката. Ока има четири литре, а у свакој литри сто драма". На овај начин ученике можемо заинтересовати за старе мјере, средства плаћања, уопште за живот српског народа у прошлости, дакле, времену у коме је пјесма настала и била пјевана, што ће засигурно допринијети њеној прецизнијој рецепцији. Сличан примјер срећемо у Читианци за 6. разред при објашњењу германизма грош стиари сребрни новаи, за који код Вука (1969:104) срећемо широко појашњење које се такође може користити као повод за даља занимљива проучавања језика и прошлости нашег народа „У пошљедњи Турски и Њемачки рат грш и форинта сребрна били су све једно (тако је турска пара била потура или крајцара и по); на свршетку 17. вијека био је грош двије цванцике (дакле пара и крајцара све једно); по том Турски новци стану све рђавији бивати и мало по мало тако спадну да данашњи грош не вриједи више од пет сребрнијех крајцара".

Пуко иревођене архаичних израза нема цјеловиту функцију појашњења њиховог значења у тексту, јер је он у цјелости настао и био прилагођен људима потпуно другог времена и животних прилика. Коришћење Срйскоі̄ рјечника омогућава контекстуално тумачење појма за шта је идеалан примјер могло бити појашњавање појма господар - муж у пјесми Највећа је жалости за брайом. Умјесто штурог йревоgа далеко би корисније и занимљи- 
вије на овом мјесту било опширно појашњење из Срйскоі̄ рјечника (95-96):

„jа сам їосйоgар од тога; ти нијеси надамном їocūogap. У Србији до 1804 године само су Турке (и то бегове и спахије) звали господарима (као и сад по Босни и херцеговини); а од онда су звали господаром Црнога Ђорђија, и остале поглаваре и војводе, који су власт у рукама имали. Тако се ова ријеч говорила у Србији и за владања Милоша Обреновића првијех година, али послије он заповиједи да се господар не зове нико осим њега и тако на остале старјешине пређе име господин. По томе се у Србији и данас само Александар Карађорђевић зове господар. У Сријему пак и осталијем Њемачкијем државама зову и најмањега трговчића господаром. У Србији су отприје знатније Србе, као свињарске трговце, звали іазgама".

Опширнија појашњења нису неопходна за сваку ријеч и она би се могла давати у посебним одјељцима уз поједине текстове. Засигурно би ученицима шестог разреда уз пјесму Свейи Саво поред упроштеног појашњења литурђија/литургија (грч) - служба божија било занимљиво и корисно понудити кратки Вуков етнографски запис којим се у Срйском рјечнику (1969:326) појашњава термин летурђија:

„На јутрењи и на лейурђији -

У Грбљу сељаци редом сваке недјеље и празника плаћају попу по нешто за летурђију, па кад који плати онај се дан каже да је он попу летурђију йреgaо и она се летурђија зове његова, и онај дан поп с ђаком иде њему на ручак."

Ширењем основне функције превода непознатих ријечи и израза ученицима се отвара могућност за проширивање знања, али и простор за другачија тумачења од оног које нуди аутор читанке. Чињеница да је 
Вук Караџић многе појмове појашњавао примјерима из народних пјесама показује да су они итекако имали стилогену функцију која се штурим йревоgима занемарује. У истој пјесми из које је био претходни примјер налази

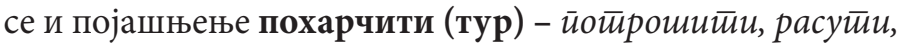
који Вук појашњава стиховима: „Ја сам њега йохарчила

Све за свилу и за злато, Док сам јаглук теб ' навезла”

На овај начин ученицима практично потврђујемо да Вук Караџић није стандардизовао колоквијални језик, него је језик народне књижевности претворио у језички стандард српског народа, за шта је могуће наћи примјер у истој читанци у приповијеци Megвjeg као йygap гдје се појам појата нетачно детерминише као стиаја за стиоку, шйала јер се не посеже за Срйским рјечником (1969: 529) у коме проналазимо „гдје сијено и слама стоји [...]:

А од њега бијел двор мирише,

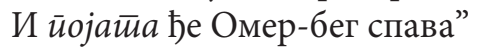

Ученицима се потом могу дати задаци да пронађу пјесме из којих су преузети наведени стихови како би се нейознайе ријечи прецизније контекстуално дефинисале.

Посебан проблем представља паушално и непрецизно коришћење извора, у овом случају Вука Стефановића Караџића. Наиме у Читанки за 4. разред након бајке Чарgак ни на небу ни на земљи стоји појашњење

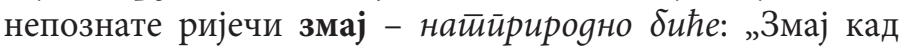
лети ноћу преко неба, онда му се особито реп сија, и од свега њега одскачу варнице”. (Вук Стефановић Караџић) Није наведено одакле је преузета ова реченица, али свакако није из Срйскої рјечника, гдје не постоји никакво објашњење овог појма, осим позивања на одреднице 
„ала, аждаха” (1969: 212). Појам ала се уз бајку Биберче у петом разреду појашњава терминима ажgаја, змај, што нас враћа на Срйски рјеник (3) у коме уз појмове аждаха и змај не постоје шира објашњења, али се уз термин ала, на који се оба упућују, даје веома лијепо објашњење „За алу се мисли да има од аждахе особиту духовну силу те лети и води облаке и град наводи на љетину. За змаја пак мисли се да је као огњевит јунак, од којега у лећењу огањ одскаче и свијетли."

Ученицима четвртог разреда се уз текст $М о \delta a$ Крсно име - Сваки Србин има йо јеgан gан у іолини који он слави и йо се зове крсно име. Домаћин се сйара и ирриирема иијеле іолине како ће ироставитии крсно име (Вук Стефановић Караџић) на 306. страници Срйскої рјечника проналазимо објашњење овог појма на читавој страници из којег можемо препознати двије почетне реченице које у извору гласе: „Сваки Србин има по један дан у години, кога он слави, и то се зове крсно име, светй, свето или благи дан. Домаћин се стара и приправља за цијелу годину како ће и с чим ће прославити крсно име”. Овдје имамо примјер гдје аутор преправља интегрални Вуков текст, вјероватно с циљем да га прилагоди ученицима, што је недопустиво.

Да се не смије увијек и слијепо држати Вука показује примјер уз приповијетку Еро и каgија гдје се појам Еро појашњава као назив за Хериеі̄овце, како га детерминише и Вук (1969: 805), мада нам је познато из контекста да се тим надимком у шаљивим народним приповијеткама именују становници Ужица и његове околине, а чему потврду проналазимо у Речнику срйскої језика (2007:156):

„Ера и Еро а. Хериеіоовац. б. (понекад пеј. или шаљ.) човек из ужичкої краја, Ужичанин."

Сви ови примјери показују да се феномену нейознатие ријечи и изрази у назначеним читанкама пришло 
на погрешан начин, да је за немали број примјера дато погрешно појашњење и да није искориштен велики простор које оне нуде за повезивање са другим наставним предметима који се на различите начине баве феноменима националне историје и традиције. Кад се критикују уџбеници у цјелини или њихови поједини сегменти ваља имати на уму промишљање Рајне Драгићевић (2012: 168):

„Наши наставници, начелно, имају отпор према уџбеницима и тај отпор увек постоји. Не сећам се да сам икад чула наставника који је похвалио уџбеник по којем предаје. Нарочито су на лошем гласу нови уџбеници. Они су, обично, унапред оцењени као лоши и, по мишљењу наставника, скоро су редовно лошији од претходних.”

Без намјере да наречене уџбенике прогласимо лошим настојали смо показати како се неким веома битним сегментима у њима посвећује премало пажње и колико се у њиховом стварању уопште не користе или лоше користе фундаменталне књиге српске културе. Наиме, кориштењем Срйскоі̄ рјечника као референтног извора аутори читанки би били у могућности да ученицима понуде знатно шири спектар тумачења самог дјела, при чему би се отворио додатни простор за повезивање часова српског језика и књижевности са другим наставним предметима и садржајима. Кориштењем Срӣскої рјечника у самој наставној пракси наставници би имали могућност да ученицима понуде један раскошни свијет националне културе који би их приближио прошлости, а самим тим и егзистенцијалној самобитности националне кутуре.

\section{Извори}

Милатовић и др. 2011: В. Милатовић, Б. Савић, П. Ђаковић, Читианка за 4. разреg основне школе, Источно Сарајево: Завод за уџбенике и наставна средства. 
Шобот, Милошевић 2018: Д. Шобот и И. Милошевић, Читианка за 5. разреg основне школе, Источно Сарајево: Завод за уџбенике и наставна средства.

Гаковић и др. 2012: В. Гаковић, С. Стефановић, С. Личина, Л.

Шекара, Читианка за 6. разреg основне школе, Источно

Сарајево: Завод за уџбенике и наставна средства.

Савић 2018: М. Савић, Читианка за 7. разреg основне школе, Источно Сарајево: Завод за уџбенике и наставна средства.

\section{Литература}

Брборић 2018: В. Брборић, Речници у читанкама за основну школу, Научни састианак слависӣа у Вукове gане, 47/1, Београд: МСЦ, 473-486.

Драгићевић 2012: Р. Драгићевић, Лексиколоіија и ірамайика у школи - метиоgички оїлеgu, Београд: Учитељски факултет. Ивић, Пешикан, Антић 2008: И. Ивић, А. Пешикан, С. Антић,

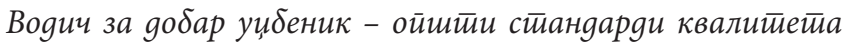
уибеника, Нови Сад: Платонеум.

Караџић 1969: В. С. Караџић, Срйски рјечник, Београд: Нолит.

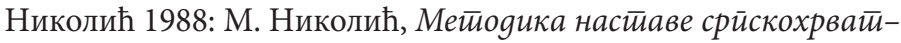
скої језика и књижевностии, Београд: Завод за уџбенике и наставна средства.

РCJ 2007: Речник срӣско̄̄ језика, Нови Сад: Матица српска. Францишковић 2011: D. Francišković, Čitanka i metodološko oblikovanje programskog sadržaja, Metodički vidici, v. 2, 12-17. 
Saša Knežević

\section{UNKNOWN WORDS AND PHRASES}

Texts from oral literature in literature books for elementary schools, as a rule, are followed by a section Unknown words and phrases, or the previously mentioned words are explained along the text. Author's obligation is to give this kind of help to the students along with this sort of text. For the most part these terms are found next to oral literature texts. In this paper we will try to establish sense and function of this entry, that is if the students vocabulary is getting richer this way and what words appear in the newest Serbian literature books, as well as to what extent do the given explanations match the entries from Vuk's Srpski rječnik.

Using Srpski rječnik as a reference source, literature book authors would be able to offer students a much wider spectrum of text interpretation. That would create more space for connecting Serbian language and literature classes with other subjects and their content. Using Srpski rječnik in class practice, the teachers would be able to offer a magnificent world of national culture to students, wich would bring them closer to the past, as well as existential intentity of national culture.

Key words: literature book, unknown words, dictionary, Srpski rjecnik, school, students 